\title{
Human health risk assessment for silver catfish Schilbe intermedius Rüppell, 1832, from two impoundments in the Olifants River, Limpopo, South Africa
}

\author{
A Addo-Bediako', SM Marr ${ }^{1 *}$, A Jooste' ${ }^{1}$ and WJ Luus-Powell ${ }^{1}$ \\ 'Department of Biodiversity, University of Limpopo, P/Bag 1106, Sovenga, 0727, South Africa
}

\begin{abstract}
As rural populations grow and rural poverty increases, consumption of fish from contaminated river systems will increase to supplement dietary protein requirements. The concentrations of metals in fish muscle tissue at two impoundments of the Olifants River (Flag Boshielo Dam and the Phalaborwa Barrage) were measured, and a human health risk assessment following Heath et al. (2004) conducted to investigate whether consumption of Schilbe intermedius from these impoundments posed a risk to human health. The results confirmed that metals are accumulating in the muscle tissue of S. intermedius. No patterns were observed in the ratios of the metals bio-accumulated at each impoundment. The human health risk assessment identified that all fish analysed exceeded the recommended levels for safe consumption for lead and chromium and about 50\% exceeded the recommended level for antimony at Flag Boshielo Dam. Almost all fish analysed exceeded the recommended level for lead and more than $50 \%$ exceeded the recommended level for arsenic at the Phalaborwa Barrage. We conclude that weekly consumption of $S$. intermedius from these impoundments may pose an unacceptable risk to the health of rural communities.
\end{abstract}

Keywords: risk assessment, human health, Schilbe intermedius, lead, chromium, antimony

\section{INTRODUCTION}

Globally, river systems have been adversely impacted by constant increases in domestic, agricultural, mining and industrial water abstraction and the release of contaminants such as metals and pesticides (Dudgeon et al., 2006; Strayer and Dudgeon, 2010; Vörösmarty et al., 2010). Although most metals and metalloids (hereafter referred to as metals) occur naturally in the biogeochemical cycle, many are released into inland waters as industrial, mining, agricultural and domestic effluents, and may be deleterious to aquatic systems (Dallas and Day, 2004). Some metals are essential micronutrients for living organisms (e.g. Co, $\mathrm{Cu}, \mathrm{Fe}, \mathrm{Mn}, \mathrm{Mo}$ and $\mathrm{Zn}$ ) but can exert toxic effects on aquatic biota when present at elevated levels (Heath and Claassen, 1999; Dallas and Day, 2004). Other metals occur naturally at very low concentrations in aquatic ecosystems and have no known physiological functions. These might be toxic even at low concentrations, but have become widely distributed as a result of human activities (e.g., $\mathrm{Cd}, \mathrm{Pb}$ and $\mathrm{Hg}$ ) (Davies and Day, 1998; Dallas and Day, 2004). The toxicity of metals in aquatic ecosystems is complex and dependent on their bioavailability. Water hardness, $\mathrm{pH}$, dissolved oxygen, temperature, salinity, interactions with other metal salts, and the presence of mineral and organic suspended solids all influence the bioavailability of metals (Chapman and Wang, 2000).

Freshwater organisms absorb pollutants from the environment (sediment and water) and their food (Chen et al., 2000; Warren and Haack, 2001). Metals do not degrade in the environment but accumulate and are incorporated into aquatic food

\footnotetext{
To whom all correspondence should be addressed

+27 15268 3317; e-mail: sean.marr@ul.ac.za

Received 15 November 2013; accepted in revised form 3 September 2014.
}

webs, concentrating up the aquatic food chain and posing a toxicity risk to organisms higher in the food chain: predatory fish, piscivorous birds, mammals and humans (Chapman and Wang, 2000). Human communities that regularly consume contaminated fish are at risk of genotoxic, carcinogenic and non-carcinogenic health impairment from long-term exposure to toxic contaminants (Du Preez et al., 2003). Thus, it has become increasingly important to assess the levels of metals in fish tissues as an indicator of metal pollution in aquatic systems (Rashed, 2001) and to determine whether the fish from impacted river systems are suitable for human consumption.

In South Africa, many rural communities rely on fish harvested from inland waters by subsistence fishers to supplement their dietary protein (Ellender et al., 2009; McCafferty et al., 2012). However, many inland waters have become contaminated due to year-on-year increases in mining, agricultural, industrial and domestic effluent releases (Ashton and Dabrowski, 2011). The Olifants River, a tributary of the Limpopo River in south eastern Africa, has been systemically impaired by acidification, industrial and agricultural chemicals, organic pollutants, and domestic waste, and is now one of the most polluted river systems in South Africa (Ashton and Dabrowski, 2011). Intensive and subsistence agriculture activities, in conjunction with mining and industrial activities in the Emalahleni-Middelburg and Ba-Phalaborwa areas, significantly impacting the water quality of the Olifants River (Ashton and Dabrowski, 2011), particularly in the Upper Olifants (Fig. 1). Acid mine drainage seeping from mines in the upper catchment (McCarthy, 2011) is resulting in the acidification of rivers and the mobilisation of metals from the sediment (McCarthy, 2011; Netshitungulwana and Yibas, 2012). There is, therefore, increasing concern regarding the long-term impact of water pollution on the aquatic ecosystem and the health of rural communities in the Olifants River catchment, especially those still 


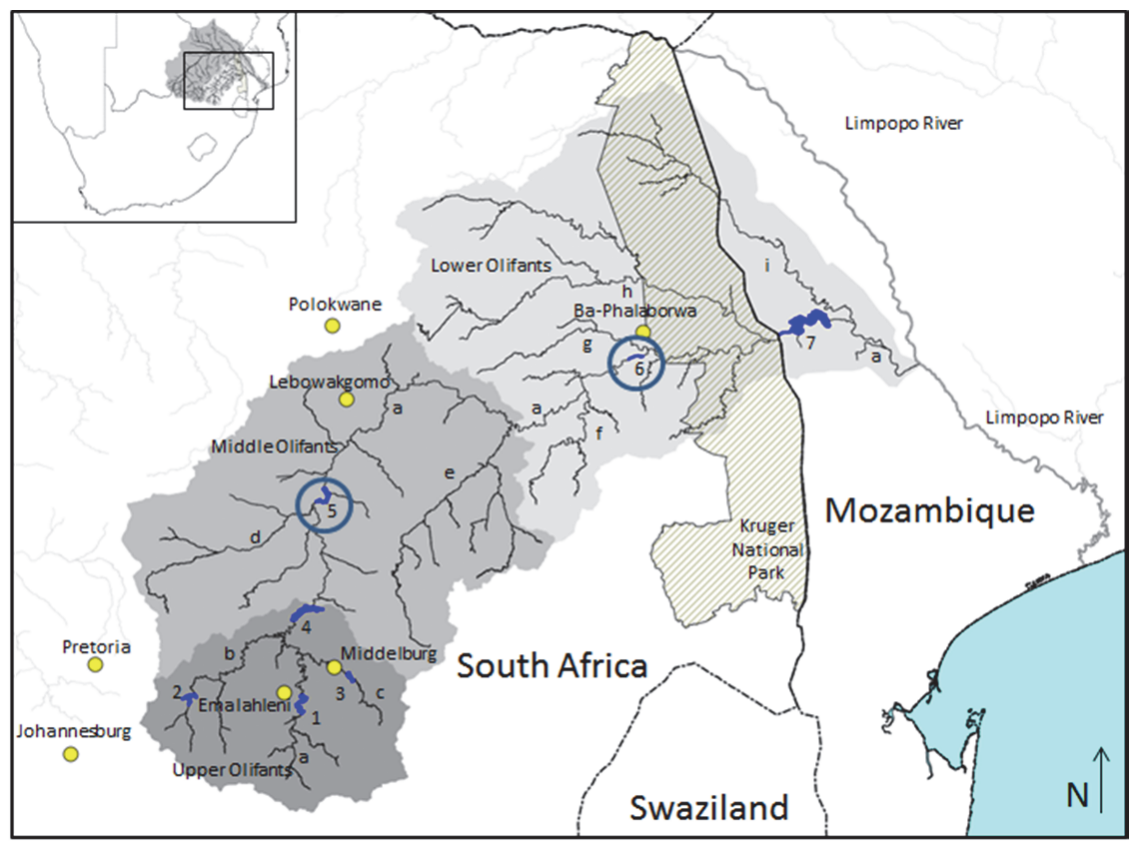

Figure 1

Map of the Olifants River system showing the location of major towns, impoundments and tributaries. Major impoundments are depicted by numbers: 1) Witbank Dam, 2) Bronkhorstspruit Dam, 3) Middelburg Dam, 4) Loskop Dam, 5) Flag Boshielo Dam, 6) Phalaborwa Barrage and 7) Massingir Dam. The Olifants River and its tributaries are depicted by letters: a) Olifants mainstem, b) Wilge, c) Klein Olifants, d) Elands, e) Steelpoort, f) Blyde, g) Ga-Selati, h) Letaba and i) Shingwedzi. The study sites, Flag Boshielo Dam and the Phalaborwa Barrage, are circled.

reliant on untreated water or aquatic resources from the river and its impoundments (Oberholster et al., 2010).

Many studies have used fish as indicators of metal pollution in aquatic systems (Rashed, 2001) because fish are at, or near, the top of the aquatic food chain (Parametrix Inc., 1995). In South Africa, several studies have assessed the accumulation of metals in selected fish tissues, many of which have focussed on the Olifants River (Grobler et al., 1994; Seymore et al., 1995; 1996a, b; Robinson and Avenant-Oldewage, 1997; Marx and Avenant-Oldewage, 1998; Nussey et al., 1999; Avenant-Oldewage and Marx, 2000a, b; Coetzee et al., 2002). The potential health risks to humans consuming contaminated fish are, however, seldom addressed (Heath et al., 2004).

Du Preez et al. (2003) identified Schilbe intermedius Rüppell, 1832 as a species to be considered for chemical contaminant investigation in South Africa. However, little is known about $S$. intermedius and it has largely been ignored in bioaccumulation studies even though it is being targeted by subsistence fishermen and consumed by rural communities. Schilbe intermedius is widely distributed throughout tropical Africa from the Nile, West and East Africa southwards to the Cunene, Okavango, Zambezi, Limpopo and Phongolo systems (Skelton, 2001). Predominantly pelagic, S. intermedius migrate to the surface at night to feed on a wide range of invertebrates and small fish (Skelton, 2001). Here, the results of the first metal bioaccumulation study for $S$. intermedius from two impoundments in the middle and lower Olifants River System, Limpopo Province, South Africa, and an assessment of the potential risk to human health posed by consuming $S$. intermedius from these impoundments are presented.

\section{MATERIALS AND METHODS}

\section{Study site}

Four major impoundments and a water extraction barrage have been constructed on the main-stem of the Olifants River: Witbank, Loskop and Flag Boshielo dams in South Africa, Massingir Dam in Mozambique, and the Phalaborwa Barrage near the border of the Kruger National Park
(Fig. 1). This study compared the autumn (March to May 2010) metal concentration in muscle tissue of $S$. intermedius from two impoundments on the Olifants River in Limpopo Province: Flag Boshielo Dam 244ㄴ $51^{\prime \prime} S ; 9^{\circ} 25^{\prime} 33^{\prime \prime} \mathrm{E}$ and the Phalaborwa Barrage 24ㄴ'12"'S; $31^{\circ} 8^{\prime} 43^{\prime \prime} \mathrm{E}$ (Fig. 1).

\section{Fish collection and analysis}

Schilbe intermedius were collected using gill nets (single net $50 \mathrm{~m}$ long, $3 \mathrm{~m}$ drop, composed of $10 \mathrm{~m}$ panels of 50 to $150 \mathrm{~mm}$ mesh, set overnight). Live fish were held in aerated tanks until processing for a parasitological study. The length and weight of each fish were recorded. The fish were sacrificed by severing the spinal cord. A skinless sample of the muscle tissue $( \pm 15 \mathrm{~g})$ was collected from a subset of the fish and frozen on site (8 from Flag Boshielo Dam and 15 from the Phalaborwa Barrage). The samples were stored at $-80^{\circ} \mathrm{C}$ prior to analysis at an accredited laboratory (ISO/IEC 17025:2005) in Pretoria. The muscle tissue samples were dried and digested according to the methods of Bervoets and Blust (2003) and analysed for metals using inductively coupled plasma-optical emission spectrometry (Perkin Elmer, Optima 2100 DV). All samples were analysed in batches with blanks. Analytical accuracy was determined using certified standards from De Bruyn Spectroscopic Solutions (500MUL20-50 STD2). Recoveries were within 10\% of the certified values. Box plots were plotted using R statistical software (R Development Core Team, 2014).

\section{Length-weight relationship and condition factor}

A length-weight relationship was determined for the combined data of the two impoundments using the standard power curve $W=a L^{b}$; where $W=$ body mass in grams; $L=$ standard length in $\mathrm{mm}$, and $a$ and $b$ are coefficients determined for the lengthweight relationship (Anderson and Neumann, 1996). An overall condition factor index was calculated using the relative weight $\left(W r=100 W / a L^{b}\right)$ as recommended by Froese (2006). An ANOVA evaluated the differences in the condition factor index between the impoundments using the ANOVA (aov) function in R. 


\section{Metal bioaccumulation}

An ANOVA evaluated whether differences between the impoundments in metal content of the muscle tissue of $S$. intermedius were significant. To evaluate differences in the multivariate metal concentrations of $S$. intermedius between the two impoundments, a resemblance matrix was constructed using Euclidean distance and a non-metric multi-dimensional scaling (NMDS) plot prepared to visualise the results using the 'Nonmetric multidimensional scaling with stable solution from random starts, axis scaling and species scores' (metaMDS) function in the VEGAN package for R (Oksanen et al., 2013). The metal concentrations were $4^{\text {th }}$ root transformed to reduce the confounding effect of metals that were present at high concentrations (e.g. iron and aluminium).

A distance-based test of homogeneity of multivariate dispersion and multiple analysis of variance (Anderson, 2001a,b; McCafferty et al., 2012) were performed to determine whether there was a statistically significant difference in the metal concentrations of $S$. intermedius from the two impoundments using the 'Multivariate homogeneity of groups dispersions (variances)' (betadisper) and 'Multi response permutation procedure and mean dissimilarity matrix' (MRPP) functions in VEGAN (Oksanen et al., 2013). The betadisper routine (hereafter DISPER) determined whether the multivariate dispersion about the group centroid differed between the impoundments, whereas the MRPP routine (hereafter MANOVA) determined whether the position of the group centroids in multivariate space and/ or the multivariate dispersion about the group centroid differed between the impoundments (Anderson, 2001a; b). A SIMPER analysis (Clarke and Warwick, 2001) was performed to determine the metals contributing most to the differences between $S$. intermedius from the two impoundments, using the 'Similarity percentages' (SIMPER) function in VEGAN. Kendall tau-B correlation coefficients were calculated for each impoundment to determine the correlation $(R)$ between the respective metals in the muscle tissue using the correlation function (cor) in $\mathrm{R}$.

\section{Human health risk assessment}

A human health risk assessment was carried out using the methodology of the US Environmental Protection Agency (US-EPA, 2000) as revised for South Africa by Heath et al. (2004). The risk of chronic non-cancer health effects from oral exposure was calculated using the Average Daily Dose (ADD) and expressed in $\mathrm{mg} / \mathrm{kg}$ body mass per day:

$A D D=\frac{\text { (average metal concentration in fish muscle }(\mathrm{fw})) \times(\text { mass of portion })}{\text { (adult body mass }) \times(\text { no. of days between fish meals })}$

where the average metal concentration is in $\mathrm{mg} / \mathrm{kg}$, mass of portion in $\mathrm{kg}$, adult body mass in $\mathrm{kg}$, and no. of days between fish meals in days.

Risk assessments evaluating non-carcinogenic toxic effects of contaminants use reference doses (RfD) as thresholds above which adverse health impacts could be expected. A Hazard Quotient (HQ) was calculated to estimate the risk to human health:

$$
H Q=\frac{A D D}{R f D}
$$

where:

$H Q<1$ suggests adverse health effects are unlikely and

$H Q>1$ suggests a high probability of adverse health effects.
In order to calculate the $A D D$, a number of assumptions were required to characterise the population at risk sensu Heath et al. (2004): 150 g portion once a week; $70 \mathrm{~kg}$ adult; and 30-year exposure (not used in the calculation, but the basis of the risk assessment). The HQ values for $S$. intermedius at each impoundment were summarised as box plots. From the box plots, the percentage of fish exceeding the recommended HQ could be estimated. The average metal concentration in the muscle tissues from each impoundment was used in the health risk assessment to reflect a long-term exposure to contaminated $S$. intermedius (Table 1). Reference dose levels published by the US-EPA Integrated Risk Information System (IRIS) were used (US-EPA, 2013); see Table 1.

\section{RESULTS}

Schilbe intermedius was the most abundant species caught at both impoundments. The composition of the catch biomass for Flag Boshielo Dam was estimated as L. rosae (31\%), O. mossambicus (27\%), C. gariepinus (24\%) and S. intermedius (18\%) and L. rosae (51\%), S. intermedius (27\%), C. gariepinus (21\%) and O. mossambicus (1\%) for the Phalaborwa Barrage (unpublished data).

\section{Length-weight relationship and relative weight}

The length-weight relationship developed for S. intermedius from the two impoundments was $W=2.632 \times 10^{-6}{ }^{\star} L^{3.293}$ $\left(n=89\right.$; Adjusted $R^{2}=0.973$ ). There was no significant difference in the size of $S$. intermedius from the two impoundments (ANOVA $p=0.135$ ), nor in the relative weight (ANOVA $p=$ 0.371 ). Schilbe intermedius was found to have positive allometric growth $(b>3.0)$. We found no clear relationship between relative weight and standard length for either impoundment (ANOVA $p>0.74$ ).

\section{Metals in muscle tissue}

The average metal concentrations in S. intermedius muscle tissue from Flag Boshielo Dam were in most cases higher than those from the Phalaborwa Barrage (ANOVA $p<0.05$, Fig. 2). The NMDS plot shows a clear separation in the metal concentrations in muscle tissues between the two impoundments (Fig. 3). DISPER returned a non-significant result $(p=0.3)$ but the MANOVA result was significant $(p<0.001)$, indicating that the separation evident on the NMDS plot for $S$. intermedius from the respective impoundments was statistically significant. The SIMPER analysis showed that about $75 \%$ of the dissimilarity between the $S$. intermedius populations could be attributed to iron, vanadium, barium, and strontium. About $88 \%$ of the similarity within the Flag Boshielo Dam population could be attributed to strontium, zinc, antimony, cobalt, and manganese, whereas about $80 \%$ of the similarity within the Phalaborwa Barrage population could be attributed to arsenic, selenium, tin, strontium, and antimony.

\section{Inter-metal relationship}

Correlations of metals within S. intermedius muscle samples from both impoundments are presented in Table A1 (Appendix). The concentrations of metals in the fish were quite variable and no patterns were observed. Only the Al:Ba correlation was greater than 0.6 at both impoundments. At Flag Boshielo Dam, Mn and Ni were strongly correlated with Ba, 

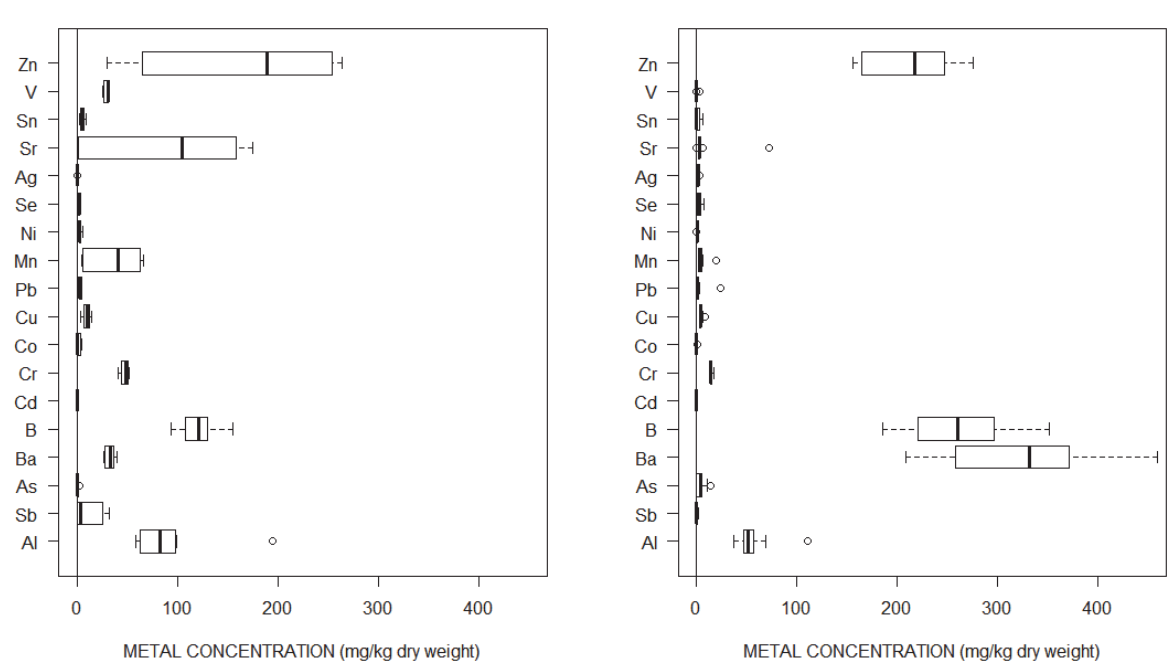

Figure 2

Box and whisker plots of metal concentrations ( $\mathrm{mg}$ / $\mathrm{kg}$ dry weight), in the muscle tissue of Schilbe intermedius from Flag Boshielo Dam and Phalaborwa Barrage.

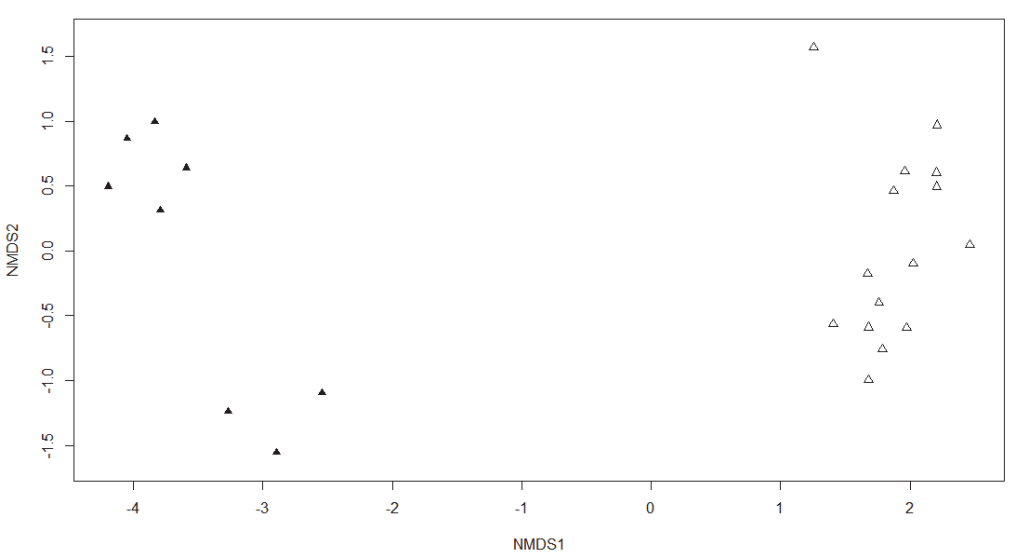

Figure 3

Non-metric multi-dimensional scaling plot for the metal concentration in the muscle tissue of Schilbe intermedius from the Flag Boshielo Dam and the Phalaborwa Barrage based on Euclidean distance and a $4^{\text {th }}$ root transform. The data points for the Flag Boshielo Dam are represented by solid symbols whereas those for the Phalaborwa Barrage are represented by open symbols.

$\mathrm{Cu}, \mathrm{Fe}, \mathrm{Sr}$ and each other, $\mathrm{Sn}$ with $\mathrm{Sb}, \mathrm{B}, \mathrm{Cr}, \mathrm{Co}, \mathrm{Pb}$ and $\mathrm{Zn}, \mathrm{Al}$ with $\mathrm{Ba}, \mathrm{Fe}$, St and $\mathrm{Ti}$, Ba with $\mathrm{Cu}, \mathrm{Fe}$, and $\mathrm{Sr}, \mathrm{B}$ with $\mathrm{Cr}$, $\mathrm{Co}$ and $\mathrm{Pb}, \mathrm{Cr}$ with $\mathrm{Co}$ and $\mathrm{Pb}$, Sb with $\mathrm{Co}$, Fe with $\mathrm{Sr}$ and $\mathrm{Zn}$ with $\mathrm{Cu}$, while at Phalaborwa Barrage Ba and B were strongly correlated with $\mathrm{Al}, \mathrm{Ag}$ and $\mathrm{Zn}$ and each other, $\mathrm{Al}$ with $\mathrm{Ag}$, and As with Se (Appendix: Table A1).

\section{Human health risk assessment}

For Flag Boshielo Dam, all S. intermedius analysed exceeded the recommended HQ of 1 for lead and chromium and about $50 \%$ exceeded the recommended HQ value for antimony, whereas for the Phalaborwa Barrage almost all S. intermedius analysed exceeded the recommended HQ of 1 for lead and more than $50 \%$ exceeded the recommended HQ value for arsenic. The weekly consumption of an average diet of $S$. intermedius from Flag Boshielo Dam exceeded the recommended HQ of 1 for antimony, chromium and lead whereas only lead exceeded the recommended HQ for the Phalaborwa Barrage (Table 1).

\section{DISCUSSION}

The lead, antimony, arsenic and chromium concentrations in the muscle tissue were comparable to results from studies of metal accumulation in Oreochromis species (Al-Kahtani, 2009; Yilmaz, 2009; Jabeen and Chaudhry, 2010; Addo-Bediako et al., 2014). The Olifants River catchment has numerous mineral deposits and is particularly rich in chrome and base metals. In addition, a number of lead, tin and antimony ore bodies have been mined in the catchment. The high levels of chromium and antimony in fish tissue could be related to the greater availability of these elements in the catchment. Acid mine drainage, prevalent in the upper catchment (Ashton and Dabrowski, 2011; McCarthy, 2011), mobilising metals from the sediment and bedrock in the Olifants River (McCarthy, 2011; Netshitungulwana and Yibas, 2012), is the main driver for the increases in metal concentrations in fish muscle tissue. The differences in metals accumulated by $S$. intermedius at the two impoundments could be attributed to differences in metal concentrations in the water and sediment at the two localities; however, no support for such a relationship was found for these sites (Jooste et al., 2014). The metal concentrations in the muscle tissue of Oreochromis mossambicus (Peters, 1852) appear to have increased at both impoundments over the past 20 years (Addo-Bediako et al., 2014), in particular the concentrations of aluminium, chromium, copper and iron, and it could be argued that a similar trend would be observed for $S$. intermedius. However, the condition factor appears to indicate that both $S$. intermedius populations were in good health.

No patterns in the correlation between metal pairs in the muscle tissue of $S$. intermedius were observed for the two impoundments. However, Jooste et al. (2014) found strong correlation coefficients between the patterns of metal accumulation in S. intermedius and three other species (Oreochromis mossambicus, Clarias gariepinus and Labeo rosae Steindachner, 1894) within each impoundment (Spearman rank correlation $\rho>0.8$ for all pairs excluding $S$. intermedius; $\rho>0.6$ for all pairs including $S$. intermedius). Schilbe intermedius is a pelagic 


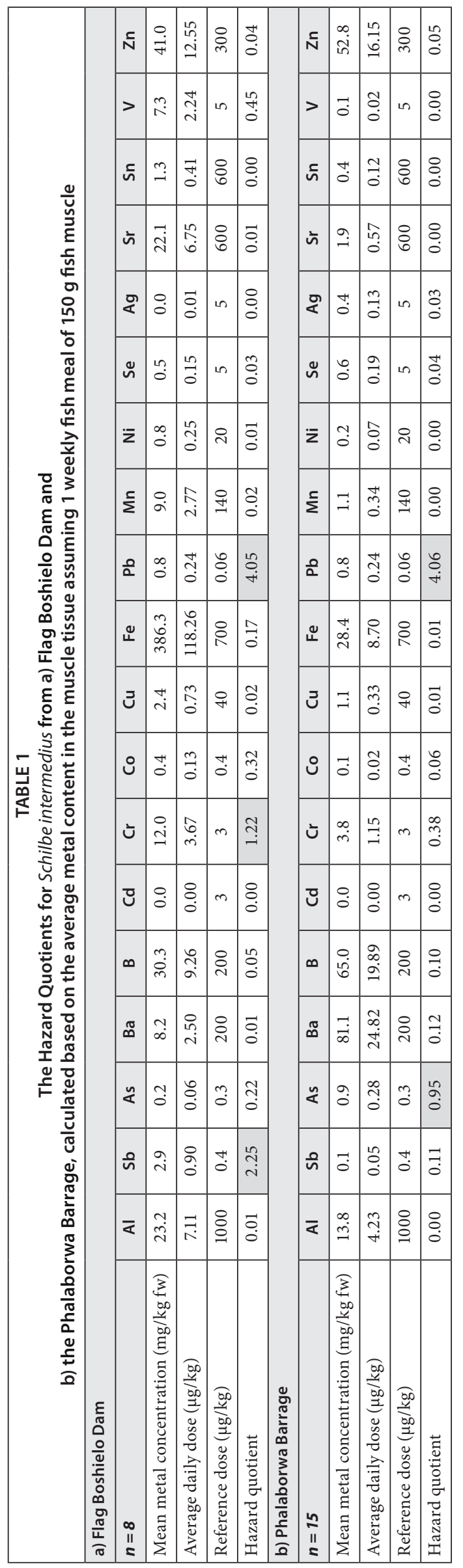

predator (Skelton, 2001) and one could speculate that the major route for assimilating metals would be from the water column and pelagic food items, whereas the other species are demersal and more susceptible to absorbing metals from the sediment and the benthic food web. Further work is required to elucidate the differences in trophic transfer of metals in the pelagic and demersal food webs.

\section{Human health risk assessment}

Fish are a vital source of food for many of the world's people, especially low-income groups (Sayer and Cassman, 2013), as they are a rich source of protein, micronutrients and essential fatty acids (Beveridge et al., 2013), cheaper than other protein sources, and available from local lakes, rivers and impoundments. However, the consumption of fish could result in detrimental health impacts when harvested from contaminated inland waters. The human health assessment revealed that certain metals, viz., lead, antimony, chromium and, to a lesser extent, arsenic, in the muscle tissue of $S$. intermedius, exceed international levels for safe consumption such that an adult consuming a $150 \mathrm{~g}$ portion once a week may be placing themselves at a health risk.

If the trend of increasing pollution levels in the Olifants River (De Villiers and Mkwelo, 2009; Ashton and Dabrowski, 2011) continues, we predict that the risks to human health posed by the consumption of contaminated fish would also increase. Considering that the rural populations will continue to grow and poverty will increasingly necessitate the supplementing of dietary protein requirements, an escalation of the frequency of consumption of fish from the impoundments may occur.

Subsistence fishers are the main source of fish to rural communities, but were historically excluded from utilising impoundments (Weyl et al., 2007; McCafferty et al., 2012). Due to limited resources, local conservation authorities no longer patrol impoundments resulting in increased illegal use of gill nets by subsistence fishers. The indiscriminate use of gill nets, unsustainable fishing pressure (McCafferty et al., 2012), and pollution are contributing to the decline in fish stocks in the Olifants River impoundments, raising concerns regarding the conservation of endemic species. However, subsistence fishing provides an income source for fishers and fish as food to the community, and is becoming an important sector in rural livelihoods (McCafferty et al., 2012). Our results indicate that fish from the impoundments of the Olifants River pose unacceptable health risks and the pollution trends in the basin (De Villiers and Mkwelo, 2009; Ashton and Dabrowski, 2011) indicate that these health risks will increase in the future.

\section{ACKNOWLEDGEMENTS}

The authors would like to thank the Water Research Commission for funding this research project. Members of the Reference Group of WRC Project No. K5/1929 are acknowledged for their assistance and the constructive discussions and inputs during the project. We would also like to thank the Belgian VLIR-IUC (Vlaamse Interuniversitaire Raad University Development Cooperation) Funding Programme, for additional funding. Our gratitude is extended to our UL colleagues, Dr Moses Matla, Willem Smit and Hendrik Hattingh, for their valuable time and input during the field surveys and laboratory work, and to our MSc students, Millicent Kekana, Ashla Gohell and Letticia Mahlatji, for all their hard work during the course of this project. 


\section{REFERENCES}

ADDO-BEDIAKO A, MARR SM, JOOSTE A and LUUS-POWELL WJ (2014) Are metals in the muscle tissue of Mozambique tilapia a threat to human health? A case study of two impoundments in the Olifants River, Limpopo, South Africa. Ann. Limnol. 50 201-210.

AL-KAHTANI MA (2009) Accumulation of heavy metals in tilapia fish (Oreochromis niloticus) from Al-Khadoud Spring, Al-Hassa, Saudi Arabia. Am. J. Appl. Sci. 6 2024-2029.

ANDERSON MJ (2001a) A new method for non-parametric multivariate analysis of variance. Aust. Ecol. 26 32-46.

ANDERSON MJ (2001b) Permutation tests for univariate or multivariate analysis of variance and regression. Can. J. Fish Aquat. Sci. $\mathbf{5 8}$ 626-639.

ANDERSON RO and NEUMANN RM (1996) Length, weight, and associated structural indices. In: Murphy BR and Willis DW (eds) Fisheries Techniques. American Fisheries Society, Bethesda, Maryland. 447482.

ASHTON PJ and DABROWSKI JM (2011) An overview of water quality and the causes of poor water quality in the Olifants River Catchment. WRC Project No. K8/887. Water Research Commission, Pretoria.

AVENANT-OLDEWAGE A and MARX HM (2000a) Bioaccumulation of chromium, copper and iron in the organs and tissues of Clarias gariepinus in the Olifants River, Kruger National Park. Water SA 26 569-582.

AVENANT-OLDEWAGE A and MARX HM (2000b) Manganese, nickel and strontium bioaccumulation in the organs and tissues of the African sharptooth catfish, Clarias gariepinus from the Olifants River, Kruger National Park. Koedoe 43 17-33.

BERVOETS L and BLUST R (2003) Metal concentrations in water, sediment and gudgeon (Gobio gobio) from a pollution gradient: relationship with fish condition factor. Environ. Pollut. 26 9-19.

BEVERIDGE MCM, THILSTED SH, PHILLIPS MJ, METIAN M, TROELL M and HALL SJ (2013) Meeting the food and nutrition needs of the poor: the role of fish and the opportunities and challenges emerging from the rise of aquaculturea. J. Fish Biol. 83 1067-1084.

CHAPMAN PM and WANG F (2000) Issues in ecological risk assessment of inorganic metals and metalloids. Hum. Ecol. Risk Assess. 6 965-988.

CHEN CY, STEMBERGER RS, KLAUE B, BLUM JD, PICKHARDT PC and FOLT CL (2000) Accumulation of heavy metals in food web components across a gradient of lakes. Limnol. Oceanogr. 45 1525-1536.

CLARKE KR and WARWICK RM (2001) Change in Marine Communities: An Approach to Statistical Analysis and Interpretation ( $2^{\text {nd }}$ edn). PRIMER-E: Plymouth Marine Laboratory, Plymouth.

COETZEE L, DU PREEZ HH and VAN VUREN JHJ (2002) Metal concentrations in Clarias gariepinus and Labeo umbratus from the Olifants and Klein Olifants River, Mpumalanga, South Africa: zinc, copper, manganese, lead, chromium, nickel, aluminium and iron. Water SA 28 433-448.

DALLAS HF and DAY JA (2004) The effect of water quality variables on aquatic ecosystems: A review. WRC Report No. TT 224/04. Water Research Commission, Pretoria.

DAVIES BR and DAY JA (1998) Vanishing Waters. University of Cape Town Press, Cape Town.

DE VILLIERS S and MKWELO ST (2009) Has the monitoring failed the Olifants River, Mpumalanga? Water SA 35 671-676.

DU PREEZ HH, HEATH RGM, SANDHAM LA and GENTHE B (2003) Methodology for the assessment of human health risks associated with the consumption of chemical contaminated freshwater fish in South Africa. Water SA 29 69-90.

DUDGEON D, ARTHINGTON AH, GESSNER MO, KAWABATA Z-I, KNOWLER DJ, LÉVÊQUE C, NAIMAN RJ, PRIEUR-RICHARD A-H, SOTO D, STIASSNY MLJ and SULLIVAN CA (2006) Freshwater biodiversity: importance, threats, status and conservation challenges. Biol. Rev. 81 163-182.

ELLENDER BR, WEYL OLF and WINKER H (2009) Who uses the fishery resources in South Africa's largest impoundment?
Characterising subsistence and recreational fishing sectors on Lake Gariep. Water SA 35 677-682.

FROESE R (2006) Cube law, condition factor and weight-length relationships: history, meta-analysis and recommendations. J. Appl. Ichthyol. 22 241-253.

GROBLER DF, KEMPSTER PL and VAN DER MERWE L (1994) A note on the occurrence of metals in the Olifants River, Eastern Transvaal, South Africa. Water SA 20 195-204.

HEATH RGM and CLAASSEN MC (1999) An overview of the pesticide and metal levels present in populations of the larger indigenous fish species of selected South African Rivers. WRC Report No. 428/1/99. Water Research Commission, Pretoria.

HEATH RGM, DU PREEZ HH, GENTHE B and AVENANTOLDEWAGE A (2004) Freshwater fish and human health. Reference guide. WRC Report No. TT 212/04. Water Research Commission, Pretoria.

JABEEN F and CHAUDHRY A (2010) Environmental impacts of anthropogenic activities on the mineral uptake in Oreochromis mossambicus from Indus River in Pakistan. Environ. Monit. Assess. 166 641-651.

JOOSTE A, LUUS-POWELL WJ and ADDO-BEDIAKO A (2014) The impact of water and sediment quality on the health of fish and the diversity of fish parasites in two impoundments of the Olifants River, Limpopo province. Final report for WRC Project No. K5/1929. Water Research Commission, Pretoria.

MARX HM and AVENANT-OLDEWAGE A (1998) A further investigation into the bioaccumulation of lead and zinc in the organs and tissues of the African sharptooth catfish, Clarias gariepinus from two localities in the Olifants River, Kruger National Park. Koedoe 41 27-43.

McCAFFERTY JR, ELLENDER BR, WEYL OLF and BRITZ PJ (2012) The use of water resources for inland fisheries in South Africa: review. Water SA 38 327-343.

McCARTHY TS (2011) The impact of acid mine drainage in South Africa. S. Afr. J. Sci. 107 1-7.

NETSHITUNGULWANA R and YIBAS B (2012) Stream sediment geochemistry of the Olifants catchment, South Africa: Implication for acid mine drainage. In: McCullough CD, Lund MA and Wyse $\mathrm{L}$ (eds) Proceedings of the International Mine Water Association Symposium. 29 September - 4 October 2012. International Mine Water Association, Bunbury, Australia, pp. 257-264.

NUSSEY G, VAN VUREN JHJ and DU PREEZ HH (1999) Bioaccumulation of aluminium, copper and zinc in the tissues of moggel from Witbank Dam, Upper Olifants River Catchment (Mpumalanga) S. Afr. J. Wildl. Res. 29 130-144.

OBERHOLSTER PJ, MYBURGH JG, ASHTON PJ and BOTHA A-M (2010) Responses of phytoplankton upon exposure to a mixture of acid mine drainage and high levels of nutrient pollution in Lake Loskop, South Africa. Ecotox. Environ. Saf. 73 326-335.

OKSANEN J, BLANCHET FG, KINDT R, LEGENDRE P, O'HARA RB, SIMPSON GL, SOLYMOS P, STEVENS MHH and WAGNER H (2013) VEGAN: Community Ecology Package version 2.0-9. URL: http://R-Forge.R-project.org/projects/vegan/.

PARAMETRIX INC. (1995) Persistence, bioaccumulation and toxicity of metals and metal compounds. International Council on Metals and the Environment, Ottawa, Canada.

R DEVELOPMENT CORE TEAM (2014) R: A language and environment for statistical computing. R Foundation for Statistical Computing, Vienna, Austria. URL: http://www.R-project.org.

RASHED M (2001) Cadmium and lead levels in fish (Tilapia nilotica) tissues as biological indicator for lake water pollution. Environ. Monit. Assess. 68 75-89.

ROBINSON J and AVENANT-OLDEWAGE A (1997) Chromium, copper, iron and manganese bioaccumulation in some organs and tissues of Oreochromis mossambicus from the lower Olifants River, inside the Kruger National Park. Water SA 23 387-404.

SAYER J and CASSMAN KG (2013) Agricultural innovation to protect the environment. Proc. Natl. Acad. Sci. $1108345-8348$.

SEYMORE T, DU PREEZ HH and VAN VUREN JHJ (1995) Manganese, lead and strontium bioaccumulation in the tissues of the yellowfish, Barbus marequensis from the lower Olifants River, Eastern Transvaal. Water SA 21 159-172. 
SEYMORE T, DU PREEZ HH and VAN VUREN JHJ (1996a) Concentration of zinc in Barbus marequensis from the lower Olifants River, Mpumalanga, South Africa. Hydrobiologia 332 141-150.

SEYMORE T, DU PREEZ HH and VAN VUREN JHJ (1996b) Concentrations of chromium and nickel in Barbus marequensis from the lower Olifants River Mpumalanga, South Africa. S. Afr. J. Zool. 31 101-109.

SKELTON PH (2001) A Complete Guide to the Freshwater Fishes of Southern Africa. Struik Publishers, Cape Town.

STRAYER DL and DUDGEON D (2010) Freshwater biodiversity conservation: recent progress and future challenges. J. N. Am. Benthol. Soc. 29 344-358.

US-EPA (UNITED STATES ENVIRONMENTAL PROTECTION AGENCY) (2000) Guidance for Assessing Chemical Contaminant Data for use in Fish Advisories. Volume 2: Risk Assessment and Fish Consumption Limits ( $3^{\text {rd }}$ edn). EPA 823-B-00-008. Office of Health and Environmental Assessment, Washington, DC.

US-EPA (UNITED STATES ENVIRONMENTAL PROTECTION AGENCY) (2013) Integrated Risk Information System (IRIS). United States Environmental Protection Agency, Environmental Criteria and Assessment Office. URL: http://www.epa.gov/IRIS/ (Accessed July 2013).

VÖRÖSMARTY CJ, McINTYRE PB, GESSNER MO, DUDGEON D, PRUSEVICH A, GREEN P, GLIDDEN S, BUNN SE, SULLIVAN CA and LIERMANN CR (2010) Global threats to human water security and river biodiversity. Nature 467 555-561.

WARREN LA and HAACK EA (2001) Biogeochemical controls on metal behaviour in freshwater environments. Earth-Sci. Rev. 54 261-320.

WEYL OLF, POTTS WM and ROUHANI Q (2007) The need for an inland fisheries policy in South Africa: A case study of the North West Province. Water SA 33 497-504.

YILMAZ F (2009) The comparison of heavy metal concentrations $(\mathrm{Cd}, \mathrm{Cu}, \mathrm{Mn}, \mathrm{Pb}$, and $\mathrm{Zn}$ ) in tissues of three economically important fish (Anguilla anguilla, Mugil cephalus and Oreochromis niloticus) inhabiting Koycegiz Lake-Mugla (Turkey). Turk. J. Sci. Tech. 4 7-15.

\section{Appendix}

\begin{tabular}{|c|c|c|c|c|c|c|c|c|c|c|c|c|c|c|c|c|c|c|c|c|}
\hline \multirow{6}{*}{ 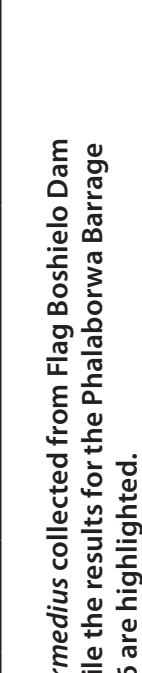 } & & & in & $\stackrel{n}{\rightarrow}$ & & $\frac{n}{n ! n}$ & & in & \begin{tabular}{l}
\multirow{U}{0}{} \\
0
\end{tabular} & $\begin{array}{l}0 \\
0 \\
0 \\
0\end{array}$ & $\begin{array}{l}\text { f } \\
0 \\
1\end{array}$ & $\left|\begin{array}{l}0 \\
10 \\
0 \\
0\end{array}\right|$ & 䓟 & 竞: & $\begin{array}{l}0 \\
0 \\
0 \\
0\end{array}$ & 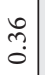 & & ֶָ. & ton & \\
\hline & & $\begin{array}{l}\text { ते } \\
\text {. }\end{array}$ & $\begin{array}{l}0 \\
\vdots \\
\vdots \\
1 \\
1\end{array}$ & $\exists$ & ָิ & & & f & ֻे & ळి & $\mid \begin{array}{l}\hat{n} \\
0 \\
0 \\
1\end{array}$ & 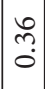 & ț & $\hat{\hat{m}}$ & $\begin{array}{l}\text { in } \\
\text { ? }\end{array}$ & त़| & $\begin{array}{l}\hat{n} \\
\vdots \\
i \\
1\end{array}$ & $\begin{array}{l}\infty \\
0 \\
0 \\
0\end{array}$ & & \\
\hline & $F$ & $\begin{array}{l}\hat{\imath} \\
\vdots \\
0\end{array}$ & $\begin{array}{l}\infty \\
0 \\
0 \\
0\end{array}$ & $\stackrel{n}{n}$ & 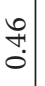 & 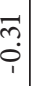 & & $\cong$ & $\stackrel{\infty}{\stackrel{0}{0}}$ & $\begin{array}{l}0 \\
\vdots \\
0\end{array}$ & $\underset{0}{\stackrel{7}{0}}$ & गึ. & 号 & 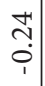 & $\begin{array}{l}\text { 苟 } \\
\vdots \\
0\end{array}$ & 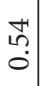 & $\begin{array}{l}\infty \\
0 \\
0 \\
1 \\
1\end{array}$ & & & \\
\hline & $\tilde{n}$ & 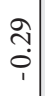 & $\begin{array}{l}\text { ப़ } \\
0\end{array}$ & $\begin{array}{l}\infty \\
0 \\
0\end{array}$ & fa & 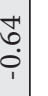 & $\pi$ & $\begin{array}{l}\infty \\
\infty \\
0\end{array}$ & in & $\begin{array}{l}\vec{N} \\
\vdots \\
i\end{array}$ & 苞 & $\mid \begin{array}{l}0 \\
10 \\
0 \\
1\end{array}$ & $\mid \begin{array}{l}0 \\
\hat{n} \\
i \\
1\end{array}$ & 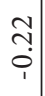 & $\begin{array}{l}\overrightarrow{0} \\
\stackrel{0}{0}\end{array}$ & $\begin{array}{l}0 \\
0 \\
0 \\
1 \\
1\end{array}$ & & $\begin{array}{c} \pm \\
\vdots \\
\vdots\end{array}$ & $\begin{array}{l}2 \\
0 \\
0 \\
1\end{array}$ & \\
\hline & is & $\begin{array}{l}\hat{\hat{O}} \\
0\end{array}$ & 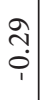 & $\begin{array}{l}\stackrel{8}{0} \\
\vdots \\
0\end{array}$ & ֵ̊. & $\begin{array}{l}8 \\
0 \\
0\end{array}$ & ؛े. & 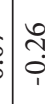 & în & 종 & $\stackrel{t}{0}$ & ה્t & $\mid \begin{array}{l}1 \\
0 \\
0 \\
0\end{array}$ & $\begin{array}{l}1 \\
0 \\
0 \\
0 \\
1\end{array}$ & 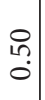 & & $\begin{array}{c}0 \\
\substack{1 \\
1}\end{array}$ & ָุ| & ָे. & \\
\hline & 8 & $\begin{array}{l}0 \\
1 \\
0 \\
0\end{array}$ & 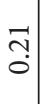 & $\begin{array}{l}\tilde{丶} \\
0\end{array}$ & $\begin{array}{l}0 \\
\stackrel{0}{0} \\
0 \\
0\end{array}$ & 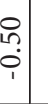 & 疍 & $\stackrel{\pi}{\approx}$ & $\stackrel{\circ}{0}$ & 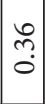 & ก̂? & $\overrightarrow{\tilde{T}}$ & $\begin{array}{l}0 \\
\vdots \\
0\end{array}$ & $\begin{array}{l}n \\
n \\
i \\
1\end{array}$ & & $\stackrel{8}{\circ}$ & $\begin{array}{l}0 \\
\stackrel{0}{0} \\
\end{array}$ & \begin{tabular}{l}
0 \\
\multirow{0}{0}{} \\
0
\end{tabular} & $\frac{n}{6}$ & \\
\hline $\begin{array}{c}0 \\
0\end{array}$ & $\backsim$ & $\begin{array}{l}1 \\
0 \\
0 \\
1\end{array}$ & 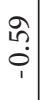 & 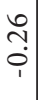 & $\begin{array}{l}\hat{0} \\
\dot{0} \\
1\end{array}$ & 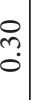 & $\stackrel{\leftrightarrow}{0}$ & $\underset{1}{f}$ & $\stackrel{8}{\circ}$ & $\frac{1}{2}$ & $\begin{array}{l}0 \\
\text { ôn } \\
i \\
1\end{array}$ & $\mid \begin{array}{l}0 \\
\vdots \\
0\end{array}$ & $\begin{array}{l}\infty \\
0 \\
0\end{array}$ & & 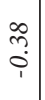 & $\begin{array}{l}\begin{array}{l}7 \\
\vdots \\
i\end{array}\end{array}$ & î. & 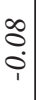 & $\begin{array}{c}2 \\
\bar{i}\end{array}$ & \\
\hline है & $\bar{z}$ & 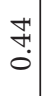 & 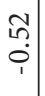 & $\begin{array}{l}\stackrel{0}{1} \\
\stackrel{0}{0}\end{array}$ & $\begin{array}{l}\stackrel{1}{0} \\
0\end{array}$ & 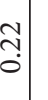 & m. & $\begin{array}{l}13 \\
\vdots \\
0\end{array}$ & aे & $\begin{array}{l}\hat{b} \\
0 \\
0\end{array}$ & 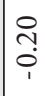 & {$\left[\begin{array}{l}0 \\
0 \\
0\end{array}\right.$} & & 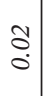 & $\begin{array}{c}\vec{m} \\
0\end{array}$ & $\begin{array}{l}\stackrel{n}{0} \\
\dot{0}\end{array}$ & $\stackrel{0}{-}$ & $\begin{array}{c}\vec{c} \\
0 \\
.\end{array}$ & $\begin{array}{l}8 \\
: \\
\end{array}$ & \\
\hline & $\frac{c}{\Sigma}$ & 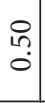 & $\begin{array}{l}m \\
\stackrel{9}{0} \\
i \\
1\end{array}$ & $\begin{array}{l}\stackrel{2}{n} \\
0 \\
0\end{array}$ & $\begin{array}{l}\hat{\imath} \\
0\end{array}$ & $\begin{array}{l}\sharp 1 \\
0 \\
0\end{array}$ & $\overrightarrow{\tilde{O}}$ & $\begin{array}{l}f \\
\text { f } \\
\end{array}$ & $\mid \begin{array}{l}0 \\
0 \\
0\end{array}$ & 종 & $\begin{array}{l}\text { Z } \\
\text { i }\end{array}$ & & $\mid \begin{array}{l}\infty \\
0 \\
0 \\
\vdots\end{array}$ & 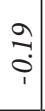 & $\approx$ & $\stackrel{\circ}{0}$ & 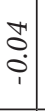 & \begin{tabular}{l}
\multirow{2}{n}{} \\
$\vdots$ \\
1
\end{tabular} & $\begin{array}{c}0 \\
\stackrel{2}{1} \\
i\end{array}$ & \\
\hline & $\therefore$ & $\begin{array}{l}z \\
\vdots \\
\vdots \\
1\end{array}$ & $\begin{array}{l}\mathfrak{I} \\
0 \\
0\end{array}$ & $\begin{array}{l}\infty \\
0 \\
0 \\
1\end{array}$ & 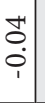 & | & $\begin{array}{l}\hat{I} \\
\text { con }\end{array}$ & $\stackrel{8}{0}$ & : & $\Rightarrow$ & & $\begin{array}{l}\tilde{0} \\
\dot{0}\end{array}$ & $\stackrel{\sim}{\Im}$ & 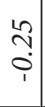 & $\begin{array}{l}m \\
\vdots \\
0\end{array}$ & $\begin{array}{l}3 \\
\text { ?. } \\
0\end{array}$ & $\stackrel{8}{\circ}$ & ঙ̊. & 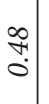 & \\
\hline $\begin{array}{l}\vec{u} \\
\end{array}$ & 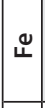 & $\begin{array}{l}\vec{b} \\
\vdots \\
0\end{array}$ & & $\overrightarrow{0}$ & $\begin{array}{l}\stackrel{+}{b} \\
\text { : }\end{array}$ & 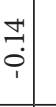 & 官 & $\underset{i}{Z}$ & in & & $\stackrel{8}{\circ}$ & $\begin{array}{l}8 \\
0 \\
\end{array}$ & $\stackrel{-}{0}$ & 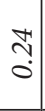 & 7 & 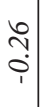 & 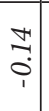 & $\begin{array}{l}m \\
0 \\
1\end{array}$ & $\stackrel{2}{\circ}$ & \\
\hline & Ј & 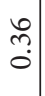 & $\begin{array}{c}\text { fol } \\
\stackrel{1}{1}\end{array}$ & $\begin{array}{l}\stackrel{\infty}{0} \\
0\end{array}$ & 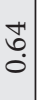 & ָे. & तु & F & & $\stackrel{8}{\circ}$ & 童 & $\stackrel{2}{0}$ & 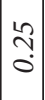 & $\mid \begin{array}{l}0 \\
\vdots \\
\dot{1}\end{array}$ & $\stackrel{2}{0}$ & $\begin{array}{l}z \\
\vdots \\
i\end{array}$ & $\begin{array}{l}\stackrel{\pi}{0} \\
\check{0}\end{array}$ & 7 & 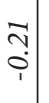 & \\
\hline & $\diamond$ & $\begin{array}{l}= \\
\overline{0} \\
1\end{array}$ & $\begin{array}{l}\hat{N} \\
0 \\
0\end{array}$ & $\begin{array}{l}\infty \\
0 \\
0 \\
\vdots \\
1\end{array}$ & 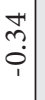 & 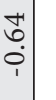 & i & & 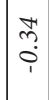 & $\begin{array}{l}0 \\
0 \\
0 \\
i\end{array}$ & $\tilde{N}$ & \begin{tabular}{|c|}
$m$ \\
0 \\
1 \\
1
\end{tabular} & $\mid$\begin{tabular}{l}
$\infty$ \\
\multirow{2}{*}{} \\
0 \\
1
\end{tabular} & 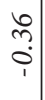 & 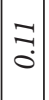 & $\widehat{\hat{m}}$ & 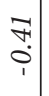 & $\begin{array}{l}1 \\
\vdots \\
i \\
1\end{array}$ & 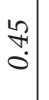 & \\
\hline & ப & $\begin{array}{l}8 \\
\vdots \\
\circ\end{array}$ & 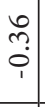 & $\begin{array}{l}\vec{z} \\
\overrightarrow{0} \\
i\end{array}$ & $\stackrel{\sharp}{:}$ & $\hat{\varrho}$ & & $\begin{array}{l}\infty \\
\substack{i \\
i}\end{array}$ & $\underset{0}{7}$ & $\frac{2}{0}$ & $\stackrel{2}{3}$ & $\mid \begin{array}{l}0 \\
0 \\
0\end{array}$ & $\frac{2}{0}$ & $\stackrel{2}{2}$ & o. & $\stackrel{m}{0}$ & 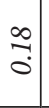 & $\stackrel{\overbrace{}}{\Im}$ & 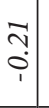 & \\
\hline & उ & & & & & & & & & & & & & & & & . & & & \\
\hline & $\infty$ & $\begin{array}{l}1 \\
0 \\
0 \\
1\end{array}$ & $\begin{array}{l}\text { సे. } \\
\text { i. }\end{array}$ & $\begin{array}{c}\vec{z} \\
\vdots \\
1\end{array}$ & $\begin{array}{l}\hat{0} \\
\stackrel{0}{0}\end{array}$ & & $\stackrel{?}{\circ}$ & $\hat{\hat{y}}$ & $\stackrel{\partial}{\circ}$ & õ & के & 号 & 7 & 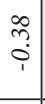 & $\mid \begin{array}{l}6 \\
0 \\
0\end{array}$ & $\begin{array}{l}0 \\
\vdots \\
0\end{array}$ & 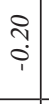 & તુ. & స్. & \\
\hline & $\infty$ & $\begin{array}{l}\hat{\imath} \\
0\end{array}$ & 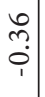 & $\stackrel{f}{\circ}$ & & $\begin{array}{l}\infty \\
\vdots \\
0\end{array}$ & $\stackrel{2}{\circ}$ & $\stackrel{2}{2}$ & $\stackrel{0}{0}$ & $\begin{array}{l}a \\
0 \\
0\end{array}$ & $\underset{7}{\stackrel{7}{0}}$ & 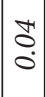 & $\dot{\partial}$ & $\left.\mid \begin{array}{c}0 \\
0 \\
0 \\
0 \\
1\end{array}\right]$ & $\mid \begin{array}{l}0 \\
0 \\
0 \\
0\end{array}$ & $\begin{array}{c}\infty \\
\stackrel{0}{0}\end{array}$ & $\begin{array}{c}\infty \\
\stackrel{0}{1} \\
1\end{array}$ & ণิ & ふָ! & \\
\hline & $\ddot{\alpha}$ & $\stackrel{3}{0}$ & $\begin{array}{l}5 \\
0 \\
0\end{array}$ & & 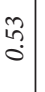 & ?. & i & $\stackrel{m}{m}$ & 苂 & §ิ & స̃ & Oे & $\begin{array}{c}7 \\
0 \\
1 \\
1\end{array}$ & $\mid \begin{array}{c}5 \\
0 \\
0\end{array}$ & {$\left[\begin{array}{l}n \\
\hat{0} \\
0\end{array}\right]$} & 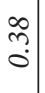 & 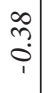 & $\stackrel{m}{0}$ & ָ̊. & \\
\hline & ติ & $\begin{array}{l}\vec{n} \\
0 \\
1\end{array}$ & & $\begin{array}{l}0 \\
\dot{0} \\
\dot{0}\end{array}$ & : & 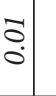 & i & $\begin{array}{l}0 \\
0 \\
0\end{array}$ & 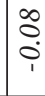 & స̃ & f & $\begin{array}{l}7 \\
0 \\
0\end{array}$ & $\mid \begin{array}{l}\infty \\
0 \\
0\end{array}$ & \begin{tabular}{l}
2 \\
\multirow{2}{0}{} \\
$\dot{1}$
\end{tabular} & $\approx$ & 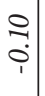 & $\begin{array}{l}\tilde{0} \\
0 \\
0\end{array}$ & 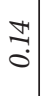 & 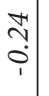 & \\
\hline & $\bar{\varangle}$ & & 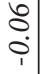 & $\begin{array}{c}0 \\
\text { के } \\
0\end{array}$ & . & | & 2 & 3 & : & $\frac{\pi}{0}$ & $\hat{m}$ & $\mid \begin{array}{l}0 \\
0 \\
0 \\
i\end{array}$ & oे & 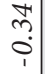 & م̂. & ?ִ. & $\begin{array}{c}\tilde{n} \\
\substack{0 \\
i}\end{array}$ & . & ֻ̊ & \\
\hline & & & & & & & & & & & & & & & & & & & & \\
\hline
\end{tabular}

http://dx.doi.org/10.4314/wsa.v40i4.5

Available on website http://www.wrc.org.za

ISSN 0378-4738 (Print) = Water SA Vol. 40 No. 4 October 2014

ISSN 1816-7950 (On-line) = Water SA Vol. 40 No. 4 October 2014 
http://dx.doi.org/10.4314/wsa.v40i4.5 Available on website http://www.wrc.org.za

ISSN 0378-4738 (Print) = Water SA Vol. 40 No. 4 October 2014 ISSN 1816-7950 (On-line) = Water SA Vol. 40 No. 4 October 2014 